\title{
Effects of global climate change on agriculture: an interpretative review
}

\author{
Richard M. Adams ${ }^{1, *}$, Brian H. Hurd², Stephanie Lenhart ${ }^{2}$, Neil Leary ${ }^{3}$ \\ ${ }^{1}$ Department of Agricultural and Resource Economics, Oregon State University, C orvallis, Oregon 97331, USA \\ ${ }^{2} \mathrm{H}$ agler, Bailly, Inc., Boulder, C olorado 80306, USA \\ ${ }^{3}$ U.S. Environmental Protection Agency, Washington, DC 20460, USA
}

\begin{abstract}
Climate is the primary determinant of agricultural productivity. Concern over the potential effects of long-term climatic change on agriculture has motivated a substantial body of research over the past decade. This body of research addresses possible physical effects of climatic change on agriculture, such as changes in crop and livestock yields, as well as the economic consequences of these potential yield changes. This paper reviews the extant literature on these physical and economic effects and interprets this research in terms of common themes or findings. Of particular interest are findings concerning the role of human adaptations in responding to climate change, possible regional impacts to agricultural systems and potential changes in patterns of food production and prices. Limitations and sensitivities of these findings are discussed and key areas of uncertainty are highlighted. Finally, some speculations regarding issues of potential importance in interpreting and using information on climate change and agriculture are presented.
\end{abstract}

KEY WORDS: Climate change - Agriculture - Economic consequences · Regional effects · Adaptations · Uncertainty

\section{INTRODUCTION}

Climate is the primary determinant of agricultural productivity. Given the fundamental role of agriculture in human welfare, concern has been expressed by federal agencies and others regarding the potential effects of climate change on agricultural productivity. Interest in this issue has motivated a substantial body of research on climate change and agriculture over the past decade.

Climate change is expected to influence crop and livestock production, hydrologic balances, input supplies and other components of agricultural systems. However, the nature of these biophysical effects and the human responses to them are complex and uncertain. For example, crop and livestock yields are directly affected by changes in climatic factors such as temperature and precipitation and the frequency and severity of extreme events like droughts, floods, and wind storms. In addition, carbon dioxide is fundamental for plant production; rising concentrations have the

*E-mail: richard.m.adams@orst.edu potential to enhance the productivity of agroecosystems. Climate change may also change the types, frequencies, and intensities of various crop and livestock pests; the availability and timing of irrigation water supplies; and the severity of soil erosion.

A gricultural systems are managed ecosystems. Thus, the human response is critical to understanding and estimating the effects of climate change on production and food supply. Agricultural systems are also dynamic; producers and consumers are continuously responding to changes in crop and livestock yields, food prices, input prices, resource availability, and technological change. Accounting for these adaptations and adjustments is difficult but necessary in order to measure accurately climate change impacts. Failure to account for human adaptations, either in the form of short-term changes in consumption and production practices or long-term technological changes, will overestimate the potential damage from climate change and underestimate its potential benefits.

This review synthesizes research on the physical and economic effects of climate change on agriculture, 
drawing primarily on experiences in North and South A merica. The primary objectives are to review similarities and differences in this research and to identify common themes and lessons. As a part of this identification process, we summarize (1) key findings regarding the role of human adaptations in responding to potential climate change; (2) significant differences in possible regional impacts to agricultural systems; (3) possible distributional consequences (i.e. winners and losers); and (4) potential changes in the level and patterns of food production and prices.

The paper builds on recent summaries of agricultural effects (Easterling 1996, IPCC 1996, Schimmelpfennig et al. 1996). Findings from the U.S. and Latin America are highlighted, although some general evidence regarding world agricultural production is reviewed. Numerical estimates presented here should be interpreted as illustrative of the possible consequences of climate change, from which more general, qualitative conclusions might be drawn. Estimates of changes in agricultural production are dependent upon: how climate changes at regional scales; assumptions regarding adaptation by producers and consumers; future technologies; population and income growth; land degradation; macroeconomic conditions; changes in international trade barriers; and changes in social and political conditions. The results are also sensitive to the assessment methods and models employed in these estimation exercises.

In Section 2, the biophysical dimensions of climate and agriculture are described, followed by a description of adaptation in the agricultural system. Adaptation plays a critical role in translating the physical changes in climate and crop response (e.g. yields) into changes in agricultural production, prices, welfare, trade and food supply. We highlight this role in Section 3 to underscore the issues of adaptation and adjustment costs, implementation constraints, and uncertainty in both detecting signals of climate change and determining the potential for adaptation responses. Section 4 summarizes the effects of climate change on crop and livestock yields, and reviews the implications of those effects on production, prices, and economic welfare. Section 5 presents 'lessons learned' and some speculations regarding issues of potential importance in interpreting and using information on climate change and agriculture.

\section{AGRICULTURE AND CLIMATE}

Plant systems, and hence crop yields, are influenced by many environmental factors, and these factors, such as moisture and temperature, may act either synergistically or antagonistically with other factors in determining yields (Waggoner 1983). Controlled field experiments can generate information on how the yield of a specific crop variety responds to a given stimulus, such as water or fertilizer. However, by their nature, such controlled experiments consider only a limited range of environmental factors.

An alternative approach to estimate crop yield (changes) is the use of crop biophysical simulation models that embed parameters drawn from crop experiments (Ritchie et al. 1989). Because climate change is likely to cut across a host of environmental factors, most quantitative estimates of climate change effects on crop yields are derived from such crop simulation models (e.g. Rosenzweig \& Parry 1994). While the use of crop simulation models makes tractable the assessment of climate effects across a range of crops, such models also have limitations, including isolation from the variety and variability of factors and conditions that affect production in the field.

Plausible climate change scenarios include higher temperatures, changes in precipitation, and higher atmospheric $\mathrm{CO}_{2}$ concentrations. Although temperature increases can have both positive and negative effects on crop yields, in general, temperature increases have been found to reduce yields and quality of many crops, most importantly cereal and feed grains. ${ }^{1}$ Increases in precipitation (i.e. level, timing and variability) may benefit semi-arid and other watershort areas by increasing soil moisture, but could aggravate problems in regions with excess water, while a reduction in rainfall could have the opposite effect. An atmosphere with higher $\mathrm{CO}_{2}$ concentration would result in higher net photosynthetic rates ( $\mathrm{Cure} \&$ Acock 1986, Allen et al. 1987). Higher concentrations may also reduce transpiration (i.e. water loss) as plants reduce their stomatal apertures, the small openings in the leaves through which $\mathrm{CO}_{2}$ and water vapor are exchanged with the atmosphere. ${ }^{2}$

The net change in crop yields is determined by the balance between these negative and positive direct effects on plant growth and development, and by indirect effects that can affect production. These indirect effects have been largely ignored in the assessment of climate change effects. Indirect effects may arise from

\footnotetext{
${ }^{1}$ Temperature increases lead to higher respiration rates, shorter periods of seed formation and, consequently, lower biomass production. For example, higher temperatures result in a shorter grain filling period, smaller and lighter grains and, therefore, lower crop yields and perhaps lower grain quality (i.e. lower protein levels)

${ }^{2}$ The reduction in transpiration could be $30 \%$ in some crop plants (Kimball 1983). However, stomatal response to $\mathrm{CO}_{2}$ interacts with many environmental (temperature, light intensity) and plant factors (e.g. age, hormones) and, therefore, predicting the effect of elevated $\mathrm{CO}_{2}$ on the responsiveness of stomata is still very difficult (Rosenzweig \& Hillel 1995)
} 
changes in the incidence and distribution of pests and pathogens (Sutherst et al. 1995), increased rates of soil erosion and degradation, and increased tropospheric ozone levels due to rising temperatures (Adams 1986). Additional indirect effects may arise from changes in runoff and groundwater recharge rates, which affect water supplies, and changes in capital or technological requirements such as surface water storage and irrigation methods. In general, these indirect effects are not captured in existing assessments (the exceptions are changes in water supplies).

\subsection{C rop response to climate change}

The effects of climate change on agricultural yields vary by region and by crop. Table 1 summarizes changes in crop yields estimated in some recent studies in North and South America. All estimates are derived from biophysical simulation models, almost exclusively the CERES family of crop models, for a few important agricultural regions within selected countries (see Ritchie et al. 1989 for a description of the CERES models).

The studies in Table 1 typically account for crop sensitivity to temperature ranges and water availability by incorporating changes in monthly averages. However, the studies generally do not account for changes in variability of climate and extreme events or indirect effects on agriculture (availability of water supplies, sea level rise, pests and pathogens, rates of soil degradation, and changes in ozone levels). Additionally, the studies generally do not assess impacts to a wide variety of crops, especially important heat-thriving crops

Table 1. Ranges of estimated climate change effects on selected crop yields in Latin and North America

\begin{tabular}{|c|c|c|c|}
\hline $\begin{array}{l}\text { Location of } \\
\text { study site }\end{array}$ & Impact (crop: percent change in yield) & Climate change scenario & Source ${ }^{b}$ \\
\hline \multicolumn{4}{|l|}{ Latin America } \\
\hline \multirow[t]{2}{*}{ Argentina } & Maize: -36 to $-17 \%$ & $\begin{array}{l}\text { GISS, GFDL, UKMO, } \\
\text { Incremental }{ }^{\mathrm{a}} \text { with and } \\
\text { without } \mathrm{CO}_{2}\end{array}$ & $\begin{array}{l}\text { Sala \& Paruelo }(1992,1994) \\
\text { (as cited in IPCC 1996) }\end{array}$ \\
\hline & $\begin{array}{l}\text { Wheat: }+3 \text { to }+48 \% \\
\text { M aize: }-4 \text { to }-18 \% \\
\text { Sunflower: }+14 \text { to }+23 \% \\
\text { Soybean: }-3 \text { to }-8 \%\end{array}$ & $\begin{array}{l}\text { GISS, GFDL, UKMO } \\
\text { with } \mathrm{CO}_{2}\end{array}$ & Magrin et al. (in press) \\
\hline Brazil & $\begin{array}{l}\text { Wheat: }-50 \text { to }-15 \% \\
\text { Maize: }-25 \text { to }-2 \% \\
\text { Soybean: }-61 \text { to }-6 \%\end{array}$ & $\begin{array}{l}\text { GISS, GFDL, UKMO, } \\
\text { Incremental }^{\mathrm{a}} \text { with } \mathrm{CO}_{2}\end{array}$ & $\begin{array}{l}\text { de Siqueira et al. (1994), } \\
\text { Siqueira (1992) } \\
\text { (as cited in IPCC 1996) }\end{array}$ \\
\hline Mexico & M aize: -61 to $-6 \%$ & $\begin{array}{l}\text { GISS, GFDL, UKMO, } \\
\text { Incremental }{ }^{\mathrm{a}} \text { with } \mathrm{CO}_{2}\end{array}$ & $\begin{array}{l}\text { Liverman \& O’Brien (1991, } \\
\text { 1994) (as cited in } \\
\text { IPCC 1996) }\end{array}$ \\
\hline \multirow[t]{2}{*}{ Uruguay } & $\begin{array}{l}\text { Barley: }-40 \text { to }-30 \% \\
\text { Wheat: }-30 \%\end{array}$ & $\begin{array}{l}\text { GISS, GFDL, UKMO, } \\
\text { Incremental }{ }^{\mathrm{a}} \text { with and } \\
\text { without } \mathrm{CO}_{2}\end{array}$ & $\begin{array}{l}\text { Baethgen (1992, 1994) } \\
\text { (as cited in IPCC 1996) }\end{array}$ \\
\hline & $\begin{array}{l}\text { Barley: }-10 \% \text { for every } 1{ }^{\circ} \mathrm{C} \text { increase } \\
\text { and }-6 \text { to }+8 \% \text { with change in precipitation } \\
\text { Maize: }-15 \% \text { for }+2^{\circ} \mathrm{C} \text { increase and } \\
-13 \text { to }+10 \% \text { with change in precipitation }\end{array}$ & Incremental ${ }^{a}$ & CNSCG (1997) \\
\hline \multicolumn{4}{|l|}{ N orth A merica } \\
\hline $\begin{array}{l}\text { Canada } \\
\text { (Alberta, } \\
\text { Manitoba, } \\
\text { Saskatchewan, } \\
\text { Ontario) }\end{array}$ & $\begin{array}{l}\text { Wheat: }-40 \text { to }+234 \% \\
\text { (results varied widely by site } \\
\text { and scenario) }\end{array}$ & $\begin{array}{l}\text { GISS, GFDL, UKMO, } \\
\text { Incremental }{ }^{\mathrm{a}} \text { with } \mathrm{CO}_{2}\end{array}$ & $\begin{array}{l}\text { Brklacich et al. (1994), } \\
\text { Brklacich \& Smit (1992) } \\
\text { (as cited in IPCC 1996) }\end{array}$ \\
\hline $\begin{array}{l}\text { United States } \\
\text { (average of } \\
\text { total U.S. } \\
\text { based on } \\
\text { selected sites) }\end{array}$ & $\begin{array}{l}\text { Wheat: }-20 \text { to }-2 \% \\
\text { M aize: }-30 \text { to }-15 \% \\
\text { Soybean: }-40 \text { to }+15 \%\end{array}$ & $\begin{array}{l}\text { GISS, GFDL, UKMO } \\
\text { with } \mathrm{CO}_{2}\end{array}$ & $\begin{array}{l}\text { Rosenzweig et al. (1994), } \\
\text { (as cited in IPCC 1996) }\end{array}$ \\
\hline
\end{tabular}


that may have different vulnerabilities to climate change than grain crops. Indeed, it is not clear that crop simulation models developed in temperate climate zones are appropriate for simulation of crop yields in tropical areas.

Despite the limitations inherent in applying crop simulation models, the studies do indicate important regional trends. For example, Rosenzweig \& Iglesias (1994) note that for a $4^{\circ} \mathrm{C}$ warming and assuming a $\mathrm{CO}_{2}$ fertilizer effect, yields in mid and high latitude countries (e.g. the northern U.S. and Canada) may increase, but yields in low latitude countries (e.g. Brazil) decline. Additionally, Rosenzweig et al. (1995) find evidence for important threshold effects. For example, their results indicate generally positive crop yield responses to temperature increases of $2^{\circ} \mathrm{C}$ rise but yield reductions at $4^{\circ} \mathrm{C}$ temperature increases. Other studies [cited in IPCC (1996) and Smith et al. 1996)] concur that crop impacts in lower latitudes tend to be more negative than crop impacts in higher latitudes, particularly with respect to wheat and maize yields. Rice yields are less variable than wheat and maize yield impacts.

Large areas of Latin America are affected by current climatic interannual variability related to the length of rainy seasons and the occurrence of extreme events (droughts, floods, etc.). The few studies conducted in the region to specifically assess the impact of climate change on agriculture revealed reductions in yields and increased variability in crop productivity. For example, runs of the GISS general circulation model for several locations in Latin America predicted temperature increases of 3.0 to $4.5^{\circ} \mathrm{C}$, and changes in rainfall of -10 to $+30 \%$. The implications of this climate change for 4 Latin American countries indicated 10 to $30 \%$ crop yield reductions (Liverman et al. 1991, Baethgen 1994, de Siqueira et al. 1994, Sala \& Paruelo 1994).

\subsection{Livestock response to climate change}

Livestock can also be affected by climate and, hence, climate change. Specifically, livestock can be affected in 2 ways by climate change: the quality and amount of forage from grasslands may be affected and there may be direct effects on livestock due to higher temperatures. There are few studies which address climate change effects on livestock, but those which do show effects on performance. For example, warmer summer temperatures are estimated to have a suppressing effect on livestock appetite, which leads to lower weight gain (Adams et al. 1998). Specifically, Adams et al. (1998) observed that under a $5.0^{\circ} \mathrm{C}$ increase in temperature, livestock yields in the U.S. fell by $10 \%$ for cow/calf and dairy operations in Appalachia, the Southeast, the Delta States, the Southern Plains, and Texas; for a $1.5^{\circ} \mathrm{C}$ warming, yield loss was estimated at $1 \%$. Hanson et al. (1993) simulated impacts on rangeland livestock production under 3 GCM (global climate model) scenarios. Climate change tended to have adverse impacts on livestock production (e.g. low milk production) through both declining forage quality and increased ambient temperature. There is evidence that intensively managed livestock systems are potentially more adaptable to climate change than crop systems because they are better able to adapt to extreme events. Some studies of mid to high latitude grasslands found higher productivity under climate change (IPCC 1996).

\section{THE ECONOMIC PERSPECTIVE: DIMENSIONS OF HUMAN RESPONSE}

Over time, humans have adapted agricultural systems and practices to changing economic and physical conditions. This has been accomplished by adopting new technologies (including investments in genetic improvements), changing crop mixes and cultivated acreages, and changing institutional arrangements. Such flexibility is suggestive of significant human potential to adapt to climate change (CAST 1992, Rosenberg 1992). For example, farm level adaptations can be made in planting and harvest dates, crop rotations, selection of crops and crop varieties for cultivation, water consumption for irrigation, use of fertilizers, and tillage practices. These adaptations are the natural consequence of producers' goals of maximizing returns to their land resource. Each adaptation can lessen potential yield losses from climate change and improve yields where climate change is beneficial. At the market level, price and other changes can signal further opportunities to adapt. Trade, both international and intranational, can reallocate supplies of agricultural commodities from areas of relative surplus to areas of relative scarcity. In the longer term, anticipatory adaptation might include the development and use of new crop varieties that offer advantages under future climates, or investments in new water management and irrigation infrastructure as insurance against potentially less reliable rainfall.

\subsection{Economic approaches to measuring climate change effects}

A number of economic approaches and models are found in existing economic assessments. A simple taxonomy of these methods is to classify them as either 
'structural' or 'spatial-analogue' approaches (Schimmelpfennig et al. 1996). The characteristics of each approach are described here.

A structural approach is interdisciplinary, using models from several disciplines to measure economic consequences of climate change. For example, the approach may start by using crop simulation models (which often have a microscale orientation of a hectare or smaller) to model yield changes by crop and then by region. This general approach thus directly incorporates the effects of climate change on yield. These crop simulation models can be adjusted to include the direct effects of increased atmospheric $\mathrm{CO}_{2}$, and specific farm-level adaptation activities such as moving planting dates, switching crops, and adding irrigation. The number of included adaptations, such as adding or enhancing irrigation, changing crop mixes, treatment of crop 'migration' potential, or changing input mixes, varies across studies.

After measuring crop yield changes under different climates (e.g. from GCM forecasts), the yield estimates can then be incorporated into economic models of the agricultural sector to estimate changes in acreage and supply by crop and by region and consequent changes in market clearing prices. The economic models seek to either minimize costs or maximize consumer and producer welfare subject to the climatic and other constraints imposed on the model. This approach has been applied at the state (Kaiser et al. 1993), regional (Easterling et al. 1993), and national level (Adams et al. 1990, 1995, 1998).

The economic models reflect varying levels of farmer adaptation and adjustment. A challenge in implementing this structural approach is to identify and incorporate the important adaptations which farmers might employ. Because these economic models also typically estimate changes in market conditions under climate change (market clearing prices), these changes can be translated into changes in aggregate well being of consumers and producers. Such calculations are needed in order to understand the distributional consequences of climate change (i.e. who gains and who loses).

In contrast to the structural models that simulate crop and farmer responses, spatial-analogue models estimate the effects of climate change on agriculture based on observed differences in agricultural production and climate between regions. Spatial-analogue models attempt to draw inferences about how cooler regions might adopt practices of warmer regions if climate warmed. A key premise is that farmers will be both able and willing to adopt the farming practices, crop varieties, and cropping practices of farmers in warmer regions.

Spatial-analogue models can use either statistical or programming methods to analyze changes in spatial patterns of production; however, both methods assume costless structural adjustment and adaptation. M endelsohn et al. (1994), for example, used a statistical approach to analyze cross-sectional data of current agricultural production across both warmer and cooler regions. They examined the relationship between agricultural land values and climate using county-level data in the United States. M endelsohn et al. referred to their procedure as the Ricardian approach because of its focus on land values. Specifically, the Ricardian approach uses regression techniques to estimate the effects of various climate, economic, and other factors on farmland values. It sidesteps the problems of understanding explicit crop and farmer responses to climate by implicitly assuming that the biophysical and economic adjustments imposed by climate change will be made automatically (an assumption that can be confirmed today by examining crops and behaviors in warmer climates), a fact common to all spatial-analogue models. The approach is based on the theory that in competitive market economies, land value is measured by the present value of expected net revenues that are derived from the most economically efficient management and use of land.

In contrast, Darwin et al. (1995) developed and combined a global computable general equilibrium (CGE) model with a geographic information system (GIS) model to analyze potential climate change impacts on U.S. agriculture, taking into account interactions with nonagricultural sectors and other global regions. The GIS component describes regional characteristics of land, climate, water, and agricultural suitability. In this approach, climate change is assumed to shift the regional land class and water characteristics, thus altering the production possibilities for a given region. The CGE component then estimates the resulting economic changes and the effects on regional and global production and price.

The strength of spatial-analogue approaches is that structural changes and farmer responses are implicit in the analysis, freeing the analyst from the burden of estimating the effects of climate change on particular region-specific crops and farmer responses. These approaches are also appealing with respect to the reasonableness of spatial adaptation as an initial response to climate change, and to the availability of spatially disaggregate data regarding current agricultural production, land values, and climate.

One weakness is that the spatial-analogue approach assumes a long-run equilibrium that ignores short- and medium-run adjustment costs. For example, the spatial-analogue model abstracts from the issues and costs of changes in structural characteristics such as irrigation systems that may be necessary to mimic warmer climate practices. The approach also ignores likely 
changes in output and input prices that result from global changes in production and affect farm-level adaptation decisions. Since market prices (changes) are not measured, effects on consumers are not captured. These approaches also assume that farmers will automatically know how and when to respond to climate changes. For example, the spatial-analogue models cannot account for changes resulting from higher $\mathrm{CO}_{2}$ concentrations, which could affect choices of crops and crop varieties not represented by the current mix. Timing of response is also a critical issue in assessing impacts. Structural models have the capability to model transient changes in climate and in farmer response.

\subsection{Adaptation and adjustment of agricultural systems to climate change}

That agricultural systems adapt to prevailing climate conditions is well documented (CAST 1992, Rosenberg 1992, Easterling et al. 1993, Kaiser et al. 1993, Easterling 1996). The consistent pattern of growth in global yields over the past $50 \mathrm{yr}$ (of approximately $2 \%$ per annum) suggests that crop yields will be higher in the future, with or without climate change. This growth is, in part, due to adoption of new technologies. A fundamental question with regard to climate change is whether agriculture can adapt quickly and autonomously or will the response be slow and dependent on structural policies and programs? The nature of the response is important because failure to account for adaption responses in assessments will overstate the potential negative impacts or understate potential positive gains associated with climate change.

Several studies (both structural and spatial analogue) describe substantial opportunities for adaptation to offset negative effects of climate change (e.g. Rosenberg 1992, Mendelsohn et al. 1994, Adams et al. 1998), but adaptation is not without costs. Changes in technology imply research and development costs, along with the costs of farm-level adoption, including possible physical and human capital investments. Changes in climate may add stress to local and regional agricultural economies already dealing with long-term economic changes in agriculture. In addition, there may be barriers to adaptation that limit responses, such as the availability of and access to financial resources and technical assistance, as well as the availability of other inputs, such as water and fertilizer. Uncertainty about the timing and rate of climate change also limits adaptation and, if expectations are incorrect, could contribute to the costs associated with transition and disequilibrium.

There are other factors that influence the adoption of new technologies. For example, rates and levels of adaptation depend on the risk preferences of farmers. Subsistence farmers have evolved farming practices that are suited to a diverse set of crops, primarily serving local or regional markets. These crops and methods may not produce the highest expected net returns, but may be more tolerant of climatic variability.

In contrast, technologically driven farming systems have contributed to a dramatic growth in global agricultural productivity. For example, selective plant breeding has led to high-yielding varieties of wheat, rice, and coarse grains such as maize, barley and sorghum which have added greatly to the world's food supply. Improved crop varieties and other technological advances result from intensive programs of research and development, driven by ongoing investments (Alston et al. 1995). However, these technologically driven farming systems may be more sensitive to climatic variability (Pope 1982, Antle 1987, Dillon \& Anderson 1990, Hurd 1994).

\subsection{Importance of adaptation assumptions in economic assessments}

The effect of adaptation assumptions on economic estimates derived from the structural approach is addressed systematically in Adams et al. (1998). Specifically, this study evaluated the effect of alternative assumptions regarding farmer adaptations and other types of adjustments on the economic effects of climate change. This evaluation is notable because it used the same economic model found in some of the first agricultural assessment studies in the U.S. (the Agricultural Sector Model or ASM). Thus, estimates from this study can be compared with earlier results (for the same climate change forecasts); differences in the economic estimates are then due to modifications in the ASM designed to simulate adaptation alternatives.

The 4 modifications in the ASM that differ from earlier ASM-based studies were (1) inclusion of some warmer season crops (tomatoes, citrus) that should benefit from warming; (2) increased possibilities of crop 'migration' (shifts in crop growing regions in response to changes in climate); (3) adjustments in specific crop yields to reflect more on-farm adaptation by farmers, based on observed behavior reported elsewhere (Segerson \& Dixon 1998); and (4) inclusion of livestock effects.

These adjustments to the ASM capture a wide range of possible adaptations or changes and can thus help resolve the issue of the role of adaptations in the assessment process. The effects of including these changes were evaluated using the GISS GCM forecast (the only GCM for which comparable forecasts 
between previous ASM assessments and the current study are available). For the GISS forecast, Adams et al. (1998) found that the modifications to the ASM resulted in approximately a $20 \%$ change in the economic estimates (from $\$ 10$ billion to $\$ 12$ billion, measured in 1990 U.S. dollars). These additional adaptations thus allowed the U.S. agricultural sector to capture more of the benefits of the modest warming forecast by GISS. Whether this $20 \%$ increase is 'important' in terms of climate change policy design is difficult to address but it is a small change in economic estimates compared with the sensitivity of the ASM model to changes in other parameters, such as future demand elasticities for domestic or foreign consumption. While this comparison is based on only 1 model and 1 set of climate forecasts, an implication is that efforts aimed at achieving a full accounting of adaptations in such assessments may be misdirected if analysts neglect other measures of sensitivity.

\subsection{Uncertainties, costs and constraints to adaptation}

Because explicit adaptation responses are difficult to project, no assessment of the agricultural effects of climate change can account for the full range of adaptation options likely to arise over the next century. Conversely, adaptation options incorporated into recent assessments may not be technically or economically feasible in some cases or in some regions. Generally, the capacity for adaptation is less in developing countries as a result of limited access to markets for crop inputs or outputs, and limited infrastructure development (Reilly \& Hohmann 1993).

Implementing adaptation often requires local access to financial and physical capital, technical assistance, and other inputs such as water and fertilizer. Infrastructure costs are also important. To the extent that climate change results in significant geographic shifts in production, costs for such support systems and infrastructure could be substantial. For these reasons, spatial-analogue models may understate the impacts of climate change.

Adaptations may involve significant time lags and long-term capital investment decisions that depend critically on the rate and variability of climate change. If climate changes at a rate that requires rapid adaptation, then the available adaptation options are limited and adjustment costs would be relatively high compared with the costs under more gradual climate change, which allows time for major infrastructure investments as systems depreciate (OTA 1993). Only structural models are capable of capturing these effects. The degree of warming is also important; studies to date examine changes in warming up to $5^{\circ} \mathrm{C}$ (based primarily on GCM model forecasts assuming an effective doubling of $\mathrm{CO}_{2}$ ). Warming beyond this level increases pressure to develop offsetting technologies (Hall 1997).

If climate uncertainty increases as the climate changes, adaptation responses will be affected. For example, if risk aversion is high among farmers in regions where water is limited, farmers may shift production from less to more drought-tolerant crops, even if expected returns are lower (Pope 1982, Dillon \& Anderson 1990, Hurd 1994). The response of farmers to changes in climate events may differ in the future as a result of the uncertainty associated with regional and local climate change.

In addition, adaptation may have unintended environmental consequences, e.g. the drive to increase production increases environmental costs owing to increased pesticide use and increased use of marginal lands (Adams et al. 1988, Crosson \& Anderson 1994).

\section{ECONOMIC IMPACTS OF CLIMATE CHANGE ON AGRIC ULTURAL SUPPLY}

Changes in agricultural supply result from the combination of changes in yields and changes in crop acreage. Changes in crop yields are the result of climate changes and any human mitigating responses (such as increasing fertilizer or water use or adoption of new crop varieties), while changes in acreage are affected by producers' expectations concerning changes in relative crop prices and per acre returns. Food costs, and the capacity to procure food, are directly affected by changes in commodity supply and resultant price changes. Crops that decline in supply will rise in price, ceteris paribus. Higher prices reduce consumption levels and adversely affect consumer welfare. In some cases, the negative effects on consumers may be partially or totally offset by producer gains from higher prices, but in general, total welfare tends to decline when supply is reduced. In the long term, higher prices stimulate producers to seek ways to increase supply, resulting in new equilibrium levels of prices and quantities.

The distribution of estimated economic effects varies across both crops and regions, just as crop yield changes vary across crops and regions. The agricultural economies of Canada and parts of the United States are estimated to be buoyed by both rising cereal and feedgrain prices and more favorable growing conditions, especially under scenarios that assume both $\mathrm{CO}_{2}$ fertilization and adaptation. In Central and South America, grain production is estimated to fall, even with $\mathrm{CO}_{2}$ fertilization and adaptation. This is because their yields decline relative to yields in high latitude countries. 


\subsection{Estimated crop supply and price response}

In general, studies that embed economic concepts and models to assess crop supply changes show significant changes in regional distribution. Adams et al. (1995) found a pattern of increased supply from more northern regions of the U.S. and declines in southern regions. Darwin et al. (1995) use a procedure similar to Mendelsohn et al. (1994) to estimate global shifts in regional supply. High latitude regions (e.g. Canada) will benefit, and low latitude regions will be harmed. Overall, however, Darwin et al. estimate that total overall global agricultural production would be largely unaffected.

The impacts of climate change are also affected by changes in market signals. The importance of marketlevel changes is illustrated in the estimates reported by Adams et al. (1995). Using estimated wheat yield changes from Rosenzweig et al. (1994; as cited in IPCC 1996) for the U.S. (shown earlier in Table 1), Adams et al. estimated a net increase in U.S. wheat supply of between 4 and $15 \%$ because of increased wheat acreage. This increase in wheat acreage is due to the overall rise in the price of wheat precipitated by falling yields. Thus, market-level changes can induce behavioral responses that mitigate impacts projected by biophysical changes alone.

Darwin et al. (1995) also demonstrated the importance of farm-level behavior in determining changes in supply. Their analysis estimated that GCM-generated changes in temperature and moisture will cause land class (growing season) shifts for approximately 30 to $45 \%$ of global land resources and 40 to $60 \%$ of cropland. Additionally, they estimated that without farmlevel adaptation, declines in global cereal production could range from 19 to $30 \%$ across the GCMs. With farm-level adaptation, declines ranged from 2.5 to $6.5 \%$. Incorporating the effects of trade flows and allowing agriculture to expand to new areas, climate change actually increased global cereal production by approximately $1 \%$. The results were based on changes in potential crop ranges, but did not include changes in yields.

The effect of climate change on prices depends on whether net increases or decreases in supply are estimated and whether demand is increased or decreased through changes in incomes, population, and the prices of related commodities. For many agricultural commodities, prices are heavily influenced by changes in global food supplies. This is the case for the major cereal and oilseed crops in the U.S. such as maize, wheat, and soybeans. For this reason, assessments of the effects of climate change on agriculture in one country or region need to reflect changes in world supplies of these commodities. For example, studies that incorporate trade patterns reveal that changes in the rest of the world have an effect on the agricultural sector in the U.S (Kane et al. 1992).

The relationship between production, prices and trade can be seen in Table 2 . Specifically, Table 2 presents indices of crop price estimates for the U.S. by Adams et al. (1998) and estimates by Darwin et al. (1995) for cereal grains. A dams et al.'s (1998) estimates are for uniform temperature and precipitation increases and a range of $\mathrm{CO}_{2}$ levels. Two scenarios are referenced in Table 2 , a modest climate change $\left(2.5^{\circ} \mathrm{C}\right.$ increase and a $7 \%$ precipitation increase) and a more severe case $\left(5.0^{\circ} \mathrm{C}\right.$ increase and $0 \%$ change in precipitation). Both assume a $\mathrm{CO}_{2}$ fertilizer effect (at $530 \mathrm{ppm}$ $\mathrm{CO}_{2}$ ). While not strictly comparable, the relatively benign scenario is similar to the GISS forecast. As the index indicates, prices fall by $20 \%$ under the benign case but increase by $15 \%$ under the adverse case. These price changes are due to an increase and decrease in crop production, respectively. Darwin et al. (1995) consistently estimated decreases in global wheat and other grain prices because of increased production, even though the model does not incorporate direct $\mathrm{CO}_{2}$ effects.

Table 2. Examples of price change forecasts, by crop group and climate assumption

\begin{tabular}{|c|c|c|c|}
\hline Study & Climate forecast assumption ${ }^{a}$ & Region & $\begin{array}{l}\text { Price change, } \\
\text { by crop group }\end{array}$ \\
\hline Adams et al. (1998) & $5^{\circ} \mathrm{C}$ warming, $0 \%$ change in precipitation, $530 \mathrm{ppm} \mathrm{CO}_{2}$ level & U.S. & All crops $^{b}+15 \%$ \\
\hline Adams et al. (1998) & $2.5^{\circ} \mathrm{C}$ warming, $7 \%$ precipitation increase, $530 \mathrm{ppm} \mathrm{CO}_{2}$ level & U.S. & All crops ${ }^{b}-19 \%$ \\
\hline Darwin et al. (1995) & UKMO & Global & $\begin{array}{l}\text { Wheat }-10 \% \\
\text { Other grains }-6 \%\end{array}$ \\
\hline Darwin et al. (1995) & GISS & Global & $\begin{array}{l}\text { Wheat }-2.5 \% \\
\text { Other grains }-3.5 \%\end{array}$ \\
\hline
\end{tabular}




\subsection{Potential impacts on economic welfare}

The changes in prices discussed above will lead to changes in the economic welfare of agricultural producers and consumers. These changes in welfare are typically measured in terms of changes in economic surplus. This is a monetary measure of producer and consumer well-being under different states of the world. Economic surplus consists of 2 components: consumer surplus and producer profits, where consumer surplus represents the difference between the maximum amount a consumer would be willing to pay for an item and the amount they actually pay. While such changes are reported in dollars, they should not be interpreted as direct changes in gross domestic product (GDP) or other macroeconomic indicators that measure levels of economic activity [economic surplus changes may indicate directional changes in GDP, but there is no direct relationship; see e.g. Scheraga et al. (1993) for a discussion of macroeconomic impacts under climate change].

Assessments of national economic welfare effects of climate change are scarce, except for the U.S. The published studies for the U.S. provide conflicting results, often within the same study. For example, the M endelsohn et al. (1994) spatial-analogue estimates for U.S. agriculture range from a loss of $\$ 120$ billion to a gain of $\$ 35$ billion (1982 U.S. \$; without direct $\mathrm{CO}_{2}$ effects). Their results are reported only for a scenario based on a $5^{\circ} \mathrm{C}$ increase and an $8 \%$ precipitation increase across the entire U.S. By comparison, Adams et al. (1995) estimated economic welfare gains of approximately $\$ 4$ and $\$ 11$ billion (1990 U.S. \$) for GISS and GFDL, respectively, under conditions reflecting increased export demands and a $\mathrm{CO}_{2}$ fertilizer effect (550 ppm CO $\mathrm{CO}_{2}$ ). However, for UKM O, a loss of $\$ 16$ billion was recorded. The study found that increased exports from the U.S., in response to high commodity prices resulting from decreased global agricultural production, lead to benefits to U.S. producers of approximately the same magnitude as the welfare losses to U.S. consumers from high prices. Estimates of changes in national welfare estimates in the more recent study by Adams et al. (1998) for a $5^{\circ} \mathrm{C}$ increase, $0 \%$ precipitation increase and $\mathrm{CO}_{2}$ level of $530 \mathrm{ppm}$ result in a welfare reduction of approximately $\$ 2$ billion (1990 U.S. \$); for modest warming of $1.5^{\circ} \mathrm{C}$ and $2.5^{\circ} \mathrm{C}$, Adams et al. report gains in welfare (of $\$ 10$ billion and $\$ 16$ billion, respectively, in 1990 U.S. \$). Reilly et al. (1994), using yield impact data from Rosenzweig \& I glesias (1994) in the Static World Policy Simulation (SWOPSIM) model, estimated increases in per capita welfare measures for the U.S. under a variety of simulation scenarios ranging from the UKMO without $\mathrm{CO}_{2}$ effects and adaptation to the GISS with both $\mathrm{CO}_{2}$ effects and adaptation.
Welfare effects are sensitive to assumptions regarding $\mathrm{CO}_{2}$, degree of temperature and precipitation change and other factors. For example, both Adams et al. (1995) and Adams et al. (1998) found positive increases in total economic welfare under $\mathrm{CO}_{2}$ fertilizer effects but losses in the absence of these effects [without the $\mathrm{CO}_{2}$ fertilizer effect, welfare losses in Adams et al. (1995) for GISS, GFDL and UKMO are -\$11 billion, $-\$ 19$ billion and $-\$ 67$ billion in 1990 U.S. $\$$, respectively]. Further, in Adams et al. (1998), excluding the $\mathrm{CO}_{2}$ fertilizer effect results in a net loss of $\$ 37$ billion in 1990 U.S. $\$$ under the $5^{\circ} \mathrm{C}$ warming, $7 \%$ precipitation scenario. Finally, studies which include measures of both consumers' and producers' welfare show that climate change has the opposite effect on producers' versus consumers' welfare (e.g. consumers typically suffer a welfare loss when supply is reduced, while producers gain).

Although trade is an important tool for maintaining global production of cereals to mitigate against regional welfare losses (Reilly et al. 1994), it is not clear how trade patterns for other crops, particularly export crops, may change. Wheat, maize, and rice are important export products. However, the traded shares of total production for these cereals are small compared to other agricultural products. About $20 \%$ of total global wheat production, $12 \%$ of coarse grains, and $3 \%$ of rice is exported. By comparison, $86 \%$ of coffee, $45 \%$ of tea, $82 \%$ of cocoa, and $85 \%$ of rubber products is exported, and more than $25 \%$ of many citrus and fiber products is exported (FAO 1995). Little research has been done on potential climate change impacts to products such as these, or on how changes in yields might affect the national economies that are highly dependent on export earnings from such products.

In addition, food imports for many countries are already relatively high, and whether they can afford to import additional food to cover yield reductions is not known. Ratios of food import value to export earnings are generally high among low latitude countries. ${ }^{3}$ Furthermore, some countries have food-import financing problems, measured as the ratio of the value of food imports to total export earnings.

\section{LESSONS LEARNED}

The above discussion summarizes key biological and economic issues involved in understanding the potential consequences of climate change. It also provides empirical evidence on the potential magnitude of these biological and economic aspects of climate change.

\footnotetext{
${ }^{3}$ For example, average ratios in Latin America are 33\%
} 
Caution should be exercised in trying to compare numerical estimates across these studies given that crops, response information, and assumed economic and environmental conditions differ considerably. However, the findings from these studies exhibit some common trends and sensitivities to imposed conditions and to data accuracy and precision.

These common traits or 'lessons learned' can serve to both summarize the major findings arising from existing research and to help bound the dimensions of the analytical and empirical problems in future assessments. Some of these common findings follow directly from 'first principles' of biological or economic science; others are more subtle and arise from the characteristics of the agricultural setting. Together, they reflect current understanding of the economic consequences of climate change for agriculture.

(1) The combined effects of warming, precipitation change, and $\mathrm{CO}_{2}$ fertilization on crop yields are expected to vary by crop, location, the magnitude of warming, the direction and magnitude of precipitation change, and the nature of the $\mathrm{CO}_{2}$ fertilization effect. Increasing temperatures, holding other factors constant, decreases crop yields while increases in precipitation lessen or offset this result. Inclusion of estimated effects of increasing concentration of $\mathrm{CO}_{2}$ on crop yields (i.e. a fertilization effect) significantly raises the yields of many crops.

(2) There are likely to be regional winners and losers from climate change, given that the potential for net reductions in crop yields is greatest in warmer, low latitude areas and semi-arid areas of the world. This implies that climate change may affect the comparative advantage of agricultural production regions. Changes in comparative advantage can be expected to shift geographically the areas in which specific crops are grown, both within countries and internationally, affect agricultural revenues of different regions and countries, and alter patterns of trade in agricultural commodities among regions and countries.

(3) The economic consequences of any yield changes will be influenced by adaptations made by farmers, consumers, government agencies, and other institutions. Farmers may adapt by changing planting dates, substituting cultivars or crops, changing irrigation practices, and changing land allocations to crop production, pasture, and other uses. Consumers may adapt by substituting relatively low priced products for those that become relatively high priced as a result of the effects of climate change. Inclusion of such adaptive responses is critical to a valid assessment, given that these responses result in less adverse effects than if such responses are excluded, and in some studies even reverse the direction of the net economic effect (from negative to positive).
(4) A lthough adaptations are highlighted by much of the recent literature, adaptation assumptions are not the only factor contributing to the diverging results between structural and spatial-analogue approaches. Divergent results also reflect differences in the ability of the models to account for both fundamental biophysical relationships, such as $\mathrm{CO}_{2}$ fertilization and basic crop yield responses to climatic changes, and the capacity of nonclimatic resources, such as soil quality and moisture availability, to support changes in the location of agricultural practices. Some research suggests that resolution of these uncertainties may improve economic assessments more than additional fine-tuning of adaptation assumptions.

(5) Difficulties in assessing adaptation responses, from the perspective of enhancing structural models, are compounded by the relatively broad and flat distributions of subjective probabilities associated with possible climate changes implied by various climate models. Until there is greater resolution with respect to estimated changes in precipitation and water availability, possible farm-level responses will remain highly speculative and limited to generalities. Furthermore, continued widespread uncertainty about possible precipitation changes will naturally delay and inhibit abilities to detect long-run shifts in climate (e.g. among farmers); may undermine support for research, education, and extension as an anticipatory response to climate change; and diffuse support for mitigation responses.

(6) Changes that are harmful for consumers are typically beneficial to producers. In several studies of U.S. agriculture that include price effects, reductions in crop yields indicate that consumers would pay higher prices and receive smaller quantities of agricultural goods, and would thereby suffer economic losses. However, because consumer demands for most crops are relatively inelastic with respect to price, declines in supply result in even greater percentage increases in prices. Consequently, growers are projected to gain on average from revenue increases in these scenarios (although growers in regions that experience particularly severe yield reductions may suffer economic losses). The economic effects on consumers are diffused over a much larger population than are producer effects, but in aggregate the effects are of roughly similar magnitude.

(7) Agriculture is a global system, linked through trade flows in commodities, inputs, technology, and knowledge. Therefore, country- and region-specific studies can only provide partial and incomplete perspectives on potential impacts. Only with a globally inclusive approach, in which regional responses are conditioned by global changes in production and price, can researchers begin to identify clearly the direction 
and magnitude of impacts for a specific region and country. Without concurrent efforts to improve global modelling, recent IPCC efforts focusing on greater spatial disaggregation are potentially self-limiting.

(8) Changes in climate are expected to affect the productivity and aggregate demand for factors of production such as water, labor, energy, equipment, and materials. Climate change is analogous to technological change in agriculture which can increase or decrease the total productivity of factors collectively and can increase or decrease the productivity of one factor relative to another. Most studies for the U.S. indicate that productivity changes triggered by climate change would generate changes in cultivated acreage by crop, total cultivated acreage, irrigation water consumption, farm employment and other changes in factor demands. The consequences of changes in factor demands on regional or local economies are largely unexplored but are potentially important.

(9) Estimates of the regional effects of climate change on agriculture are highly variable with respect to the climate change assumptions being evaluated. Because of this dependence, and because changes in regional climate cannot be predicted with a high degree of confidence, available estimates of effects cannot be relied upon as predictions of impacts to agriculture. The conditional projections found in the literature offer, instead, illustrations of possible outcomes which can aid in the assessment of the sensitivity and vulnerability of agricultural systems to climate change.

(10) Recent research has advanced understanding of the sensitivity and vulnerability of agricultural systems to climate change, but there are still a number of important omissions in assessments of impacts. Indirect effects of climate change such as changes in the incidence and severity of agricultural pests and diseases and changes in soil erosion are largely unknown and have not been incorporated into estimates of impacts. Few studies consider the effects of changes in the frequencies of extreme events such as droughts and floods, or changes in climatic variability. Costs and obstacles to adaptation have also been omitted. These omitted effects are potentially important for shaping the full impacts of climate change on agriculture.

\section{CONCLUSIONS}

Within the U.S. and the rest of the Americas, there will be both winners and losers, with some areas benefitting from increases in agricultural production as a result of climate change while other areas suffer decreases. Climate change may also affect the welfare of economic groups differently (e.g. consumers vs producers). Overall, however, the consensus of economic assessments is that climate change of the magnitudes currently being discussed by IPCC and other organizations will have only a small (likely positive) effect on U.S. agriculture.

On a global scale, the regional increases and decreases associated with climate change are not expected to result in large changes in food production over the next century. Nonetheless, impacts on regional and local food supplies in some low latitude regions could amount to large percentage changes in current production. Climate change may therefore impose significant costs on these areas. In addition, warming beyond that reflected in current studies may impose greater costs in terms of aggregate food supply. Projections from most economic studies show substantial economic losses as temperature increases beyond the equivalent of $\mathrm{a} \mathrm{CO}_{2}$ doubling. This reinforces the need to determine the magnitude of warming which may accompany the $\mathrm{CO}_{2}$ buildup currently under way in the atmosphere.

\section{LITERATURE CITED}

Adams RM (1986) A griculture, forestry and related benefits of air pollution control. Am J Agric Econ 68:885-894

Adams RM, Glyer JD, McCarl BA, Dudek DJ (1988) The implications of global change for western agriculture. West J Agric Econ 13:348-356

Adams RM, Rosenzweig C, Ritchie J, Peart R, Glyer J , M cCarl B, Curry B, J ones J (1990) Global climate change and U.S. agriculture. Nature 345:219-224

Adams RM, Fleming RA, Chang CC, M cCarl BA, Rosenzweig C (1995) A reassessment of the economic effects of global climate change on U.S. agriculture. Clim Change 30: 147-167

Adams RM, McCarl BA, Segerson K, Rosenzweig C, Bryant KJ , Dixon BL, Conner R, Evenson RE, Ojima D (1998) The economic effects of climate change on U.S. agriculture, Chap 2. In: M endelsohn R, N eumann J (eds) The economics of climate change. Cambridge University Press, Cambridge (in press)

Allen LH J r, Boote KJ , J ones J W, J ones PH, Valle RR, Acock $\mathrm{B}$, Rogers HH, Dahlman RC (1987) Response of vegetation to rising carbon dioxide: photosynthesis, biomass and seed yield of soybean. Global Biogeochem Cycles 1:1-14

Alston J M, Norton GW, Pardey PG (1995) Science under scarcity: principles and practice for agricultural research evaluation and priority setting. Cornell University Press, Ithaca, NY

Antle JM (1987) Econometric estimation of producers' risk attitudes. Am J Agric Econ 69(3):509-522

Baethgen WE (1994) Impact of climate change on barley in Uruguay: yield changes and analysis of nitrogen management systems. In: Rosenzweig C, Iglesias A (eds) Implications of climate change for international agriculture: crop modeling study. EPA 230-B-94-003. U.S. EPA Office of Policy, Planning and Evaluation, Climate Change Division, Adaptation Branch, Washington, DC, p 1-13

CAST (Council for Agricultural Science and Technology) (1992) Preparing U.S. agriculture for global climate change. Task Force Report No. 119. Council for Agricul- 
tural Science and Technology, Ames, IA

CNSCG (Comision Nacional Sobre el Cambio Global, Uruguay) (1997) Draft final report. Uruguay climate change country study: assessment of climate change impacts in Uruguay. March. CNSCG, M ontevideo

Crosson P, Anderson J R (1994) Demand and supply trends in global agriculture. Food Policy 19:105-119

Cure J D, Acock B (1986) Crop responses to carbon dioxide doubling: a literature survey. Agric For Meteorol 38: 127-145

Darwin R, Tsigas M, Lewandrowski J, Raneses A (1995) World agriculture and climate change: economic adaptations. Agricultural Economic Report No. 703. Natural Resources and Environmental Division, Economic Research Service, U.S. Department of Agriculture, Washington, DC

de Siqueira OJ F, Boucas Farias J R, Aguiar Sans LM (1994) Potential effects of global climate change for Brazilian agriculture: applied simulation studies for wheat, maize and soybeans. In: Rosenzweig C, Iglesias A (eds) Implications of climate change for international agriculture: crop modeling study. EPA 230-B-94-003. U.S. EPA, Washington, DC

Dillon J D, Anderson JR (1990) The analysis of response in crop and livestock production, 3rd edn. Pergamon Press, Oxford

Easterling WE (1996) Adapting N orth American agriculture to climate change. Agric For M eteorol 80:ix-xi

Easterling WE III, Crosson PR, Rosenberg NJ , M cKenny MS, Katz LA, Lemon KA (1993) Paper 2. Agricultural impacts of and responses to climate change in the Missouri-lowaNebraska-Kansas (MINK) region. Clim Change 24:23-61

FAO (Food and Agriculture Organization of the United Nations) (1995) The state of food and agriculture 1995. FAO, Rome

Hall D (1997) Impacts of global warming on agriculture. Proceedings, International Association of Agricultural Economists biannual meeting, Sacramento, CA, August 3-7

Hanson J D, Baker BB, Bourdon RM (1993) Comparison of the effects of different climate change scenarios on rangeland livestock production. Agric Syst 41:487-502

Hurd BH (1994) Yield response and production risk: an analysis of integrated pest management in cotton. J Agric Resour Econ 19(2):313-326

IPCC (1996) Climate Change 1995: The IPCC second assessment report, Vol 2, Scientific-technical analyses of impacts, adaptations, and mitigation of climate change, Chaps 13 and 23. In: Watson RT, Zinyowera M C, M oss RH (eds) Cambridge University Press, Cambridge, p 427-467, 745-771

Kaiser HM, Riha SJ , Wilks DS, Rossier DG, Sampath R (1993) A farm-level analysis of economic and agronomic impacts of gradual warming. Am J Agric Econ 75:387-398

Kane S, Reilly J , Tobey J (1992) An empirical study of the economic effects of climate change on world agriculture. Clim Change 21:17-35

Kimball BA (1983) Carbon dioxide and agricultural yields: an assemblage and analyses of 430 prior observations. Agron J 75:779-788

Liverman D, O'Brien KL (1991) Global warming and climate change in M exico. Global Environ Change 1:351-363

Magrin GO, Travasso MI, Rodriguez GR, Boullon R (in press) Climate change: vulnerability and adaptation of Argentina's crop production. Proceedings of the Conference on National Assessments: Impacts and Responses, March 25-28, San J ose, Costa Rica
Mendelsohn R, Nordhaus WD, Shaw D (1994) The impact of global warming on agriculture: a Ricardian analysis. Am Econ Rev 84(4):753-771

OTA (Office of Technology Assessment) (1993) Preparing for an uncertain climate. U.S. Congress, Washington, DC

Pope RD (1982) Empirical estimation and use of risk preferences: an appraisal of estimation methods that use actual economic decisions. Am J Agric Econ 63(1):161-163

Reilly J, Hohmann N (1993) Climate change and agriculture: the role of international trade. Am Econ Assoc Pap Proc 83:306-312

Reilly J , Hohmann N, Kane S (1994) Climate change and agricultural trade. Global Environ Change 4(1):24-36

Ritchie J , Singh U, Goodwin D, Hunt L (1989) A user's guide to CERES-Maize V2.10. Michigan State UniversityIFDC-IBSNAT, Muscle Shoals, AL

Rosenberg NJ (1992) Adaptation of agriculture to climate change. Clim Change 21:385-405

Rosenzweig C, Hillel D (1995) Potential impacts of climate change on agriculture and world food supply. Consequences Summer:24-32

Rosenzweig C, Iglesias A (eds) (1994) Implications of climate change for international agriculture: crop modeling study. EPA 230-B-94-003. U.S. EPA Office of Policy, Planning and Evaluation, Climate Change Division, Adaptation Branch, Washington, DC

Rosenzweig C, Parry ML (1994) Potential impact of climate change on world food supply. Nature 367:133-138

Rosenzweig C, Parry ML, Fischer G (1995) World food supply. In: Strzepek KM , Smith J B (eds) As climate changes: international impacts and implications. Cambridge University Press, Cambridge, $\mathrm{p}$ 27-56

Sala OE, Paruelo J M (1994) Impacts of global climate change on maize production in Argentina. In: Rosenzweig C, Iglesias A (eds) Implications of climate change for international agriculture: crop modeling study. EPA 230-B-94003. U.S. EPA Office of Policy, Planning and Evaluation, Climate Change Division, Adaptation Branch, Washington, DC, p 1-7

Scheraga J D, Leary NA, Goettle RJ , J orgenson DW, Wilcoxen PJ (1993) M acroeconomic modeling and the assessment of climate change impacts. Costs, impacts and possible benefits of $\mathrm{CO}_{2}$ mitigation. IIASA Collaborative Paper Series, Vol CP-93-2, p 107-132

Schimmelpfennig D, Lewandrowski J, Reilly J, Tsigas M, Parry I (1996) Agricultural adaptation to climate change: issues of long run sustainability. Agricultural Economic Report No. 740. U.S. Department of Agriculture, Natural Resource and Environment Division Economic Research Service, Washington, DC

Segerson K, Dixon B (1998) Climate change and agriculture: the role of farmer adaptation. In: Mendelsohn R, Neumann J (eds) The economic impacts of climate change on the U.S. economy. Cambridge University Press, Cambridge (in press)

Smith J B, Huq S, Lenhart S, Mata LJ , Nemesova I, Toure S (eds) (1996) Vulnerability and adaptation to climate change: a synthesis of results from the U.S. Country Studies Program. Kluwer Academic Publishers, Dordrecht

Sutherst RW, Maywald GF, Skarrate DB (1995) Predicting insect distributions in a changed climate. In: Harrington R, Stork NE (eds) Insects in a changing environment. Academic Press, London, p 59-71

Waggoner PE (1983) Agriculture and a climate changed by more carbon dioxide. Changing climate. National Academy Press, Washington, DC, p 383-418 